\title{
Association of IL $4 R$ single-nucleotide polymorphisms with rheumatoid nodules in African Americans with rheumatoid arthritis
}

\author{
Paula I Burgos1,2, Zenoria L Causey1, Ashutosh Tamhane1, James M Kelley', Elizabeth E Brown', Laura B Hughes', \\ Maria I Danila1', Amalia van Everdingen², Doyt L Conn', Beth L Jonas5, Leigh F Callahan5, Edwin A Smith6, \\ Richard D Brasington Jr7, Larry W Moreland11,8, Désirée M van der Heijde3, Graciela S Alarcón ${ }^{1}$ and S Louis Bridges Jr*1
}

\begin{abstract}
Introduction: To determine whether IL4R single-nucleotide polymorphisms (SNPS) rs 1805010 (I50V) and rs1801275 (Q551R), which have been associated with disease severity in rheumatoid arthritis (RA) patients of European ancestry, relate to the presence of rheumatoid nodules and radiographic erosions in African Americans.
\end{abstract}

Methods: Two IL4RSNPs, rs1805010 and rs1801275, were genotyped in 749 patients from the Consortium for Longitudinal Evaluation of African-Americans with Early Rheumatoid Arthritis (CLEAR) registries. End points were rheumatoid nodules defined as present either by physical examination or by chest radiography and radiographic erosions (radiographs of hands/wrists and feet were scored using the modified Sharp/van der Heijde system). Statistical analyses were performed by using logistic regression modeling adjusted for confounding factors.

Results: Of the 749 patients with RA, 156 (20.8\%) had rheumatoid nodules, with a mean age of 47.0 years, 84.6\% female gender, and median disease duration of 1.9 years. Of the 461 patients with available radiographic data, 185 (40.1\%) had erosions (score >0); their mean age was 46.7 years; $83.3 \%$ were women; and median disease duration was 1.5 years. Patients positive for HLA-DRB1 shared epitope (SE) and autoantibodies (rheumatoid factor (RF) or anti-cyclic citrullinated peptide (CCP)) had a higher risk of developing rheumatoid nodules in the presence of the AA and AG alleles of rs 1801275 (odds ratio $(O R)_{\text {adj }}=8.08$ (95\% confidence interval $\left.(\mathrm{Cl}): 1.60-40.89\right), P=0.01$ and $\mathrm{OR}_{\mathrm{adj}}=2.97(95 \% \mathrm{Cl}$, 1.08 to 8.17), $P=0.04$, respectively). Likewise, patients positive for the HLA-DRB1 SE and RF alone had a higher risk of developing rheumatoid nodules in presence of the $A A$ and $A G$ alleles of rs $1801275\left(\mathrm{OR}_{\mathrm{adj}}=8.45(95 \% \mathrm{Cl}, 1.57\right.$ to 45.44), $P=0.01$, and $\mathrm{OR}_{\mathrm{adj}}=3.57(95 \% \mathrm{Cl}, 1.18$ to 10.76$), P=0.02$, respectively) and in the presence of AA allele of rs 1805010 $\left(\mathrm{OR}_{\mathrm{adj}}=4.52(95 \% \mathrm{Cl}, 1.20\right.$ to 17.03), $P=0.03)$. No significant association was found between IL4R and radiographic erosions or disease susceptibility, although our statistical power was limited by relatively small numbers of cases and controls.

Conclusions: We found that IL4R SNPS, rs1801275 and rs1805010, are associated with rheumatoid nodules in autoantibody-positive African-American RA patients with at least one HLA-DRB1 allele encoding the SE. These findings highlight the need for analysis of genetic factors associated with clinical RA phenotypes in different racial/ethnic populations.

\section{Introduction}

Rheumatoid arthritis (RA) is a disease of unknown etiology with a prevalence of $1 \%$ in populations of European ancestry [1]; it seems to be less prevalent in patients of African

*Correspondence: Ibridges@uab.edu

1 University of Alabama, Tuscaloosa, Alabama 35487, USA

Full list of author information is available at the end of the article ancestry than in persons of European heritage [2]. Predictors of disease severity include environmental factors (socioeconomic status and smoking history), clinical factors (the number of swollen and tender joints and the presence of extraarticular manifestations and erosions at baseline) [3], laboratory data (presence of rheumatoid fac- 
tor (RF) and/or anticyclic citrullinated peptide antibodies (anti-CCP) [4], higher sedimentation rate (ESR) or C-reactive protein (CRP) levels), and other variables (educational level, score in the Health Assessment Questionnaire (HAQ)). In addition, the $H L A-D R B 1$ shared epitope (SE) has been associated with both disease severity and susceptibility [5], and other loci have been associated also with RA in multiple genome-wide association studies (GWASs) $[6,7]$. Some of these studies have used radiographic parameters to assess disease progression $[8,9]$.

It has been suggested that interleukin-4 (IL-4) and its receptor, encoded by $I L 4 R$, could play a role in the pathogenesis of RA $[8,10]$ because diminished production of IL4 may contribute to the $\mathrm{T}_{\mathrm{H}} 1$-mediated autoimmune inflammatory response characteristic of this disease $[11,12]$. Furthermore, an imbalance in the $\mathrm{T}_{\mathrm{H}} 1-$ to- $_{\mathrm{H}} 2$ ratio in the adaptive immune response occurs in a variety of immune disorders, including RA. Seven single-nucleotide polymorphisms (SNPs) have been identified in the coding region of IL4R [13-15]. Two of these SNPs, rs 1805010 (I50V) and rs1801275 (Q551R), are nonsynonymous [16] and are thought to be important in asthma and atopic diseases, as IL-4 plays a major role in IgE production $[15,17]$.

The role of rs 1805010 and rs 1801275 in RA is controversial. Prot et al. [8] reported an association of these genetic variants with the rapid development of erosions and a diminished responsiveness to IL-4 by $\mathrm{CD} 4^{+} \mathrm{T}$ cells in German RA patients, whereas Marinou et al. [18] failed to support such associations in an English population.

Because minority groups are often underrepresented in observational studies and randomized clinical trials [19,20], we evaluated in African-Americans patient with RA whether these ILR4 SNPs are associated with rheumatoid nodules and erosions, two clinical manifestations associated with disease severity. This study may improve our understanding of the disease course in these patients and possibly help to identify the presence of ethnic-specific risk factors [19-22].

\section{Materials and methods Study population}

The Consortium for the Longitudinal Evaluation of African Americans with Early Rheumatoid Arthritis (CLEAR) registry is a National Institute of Arthritis and Musculoskeletal and Skin Diseases-funded program enrolling self-identified African Americans with RA, as defined by the revised American College of Rheumatology (ACR) classification criteria [23]. Patients with disease duration of $<2$ years were enrolled in CLEAR I, a longitudinal cohort, from 2000 to 2005. Patients with any disease duration were enrolled in CLEAR II, a cross-sectional arm of the registry, beginning in 2006. Enrollment in CLEAR II is ongoing. Comprehensive demographic, clinical, and radiographic data were obtained from CLEAR I participants at the baseline visit and at 36 and 60 months from disease onset, and at one time point in CLEAR II participants. Data on current and previous drug treatments, including disease-modifying antirheumatic drugs (DMARDs), biologic agents, and glucocorticoids were collected. Participants were recruited, informed consents were obtained from study participants by study coordinators, and studies were conducted under approval by the Institutional Review Boards of the participating institutions: The University of Alabama at Birmingham (UAB) (Coordinating Center), Emory University (Atlanta, GA); The Medical University of South Carolina (Charleston), The University of North Carolina at Chapel Hill, and Washington University (St. Louis, MO). A group of 282 healthy African Americans matched for age and gender without RA, recruited as part of the CLEAR Registry, were used as a control group.

Variables ascertained included age, ethnicity, education, poverty (as defined by the United States Federal Government and adjusted for the number of subjects in the household [24]), history of RA in a first-degree relative, smoking history (self-reported ever or never), disease duration, the ACR core set of variables (number of swollen joints, number of painful joints, pain scale (assessed with a 0 to 10 Visual Analog Scale)) [25], functional status assessed with the Health Assessment Questionnaire [26], and presence of extraarticular manifestation (pulmonary fibrosis, Sjögren syndrome, pericarditis, vasculitis, skin ulcers, or scleritis). The following laboratory variables were recorded at enrollment: serum CRP measured with a high-sensitivity immunometric assay (hsCRP; Immulite 2000 Diagnostic Products, Los Angeles, CA), anti-CCP antibody (IgG) detected with a second-generation enzyme-linked immunosorbent assay (ELISA; Diastat, Axis-Shield Diagnostics, Dundee, Scotland), and rheumatoid factor measured with ELISA (INOVA Diagnostics, San Diego, CA, USA) [27].

\section{Rheumatoid nodules and radiographic erosions}

The presence of rheumatoid nodules was defined by history and physical examination at enrollment. Participants who reported a history of rheumatoid nodules on chest imaging were also considered to have rheumatoid nodules. All RA participants underwent radiographic evaluations of their hands/wrists (posteroanterior views) and feet (anteroposterior views). Study radiographs were read by an experienced reader blinded to all clinical and demographic data, who scored the radiograph for erosions and joint-space narrowing (JSN) by using the van der Heijde modified Sharp method $[28,29]$. The presence of erosions and JSN for each patient was defined by scores greater than zero; only the baseline evaluations were included in these analyses because of the limited number of follow-up radiographs in this ongoing study [30]. 


\section{DNA isolation and genotyping}

Genotypes for rs 1805010 and rs 1801275 were determined by TaqMan (Applied Biosystems (ABI), Foster City, CA) on an ABI 7900 HT Sequence Detection System. HLA$D R B 1$ shared epitope (SE) status was determined as previously described [31].

\section{Statistical analyses}

The analyses were performed by using SAS 9.1 (Cary, NC). Separate comparisons between socioeconomic, demographic, clinical, and laboratory characteristics as a function of the presence of rheumatoid nodules and erosions were performed. Categoric variables were compared by using the Pearson $\chi^{2}$ test, whereas continuous variables were compared with independent $t$ tests and the nonparametric Wilcoxon rank-sum test, where appropriate. A twotailed $P$ value of $<0.05$ was chosen as the statistically significant level. We analyzed potential associations between the IL $4 R$ SNPs and the presence of rheumatoid nodules and radiographic erosions, by using univariate and multivariate analyses. Logistic regression models were used to analyze the odds of having rheumatoid nodules and erosions as a function of the presence of $I L 4 R$ SNPs, adjusted by nodules or erosions (according to the outcome analyzed), age at RA onset, gender, disease duration ( $\geq 2$ years versus $<2$ years), smoking, and methotrexate use. The patients were stratified by the presence of autoantibodies (anti-CCP or RF positive, as one or separate), and HLA-DRB1 SE. Hardy-Weinberg equilibrium for the distribution of genotypes was examined with Fisher's Exact test.

\section{Results}

\section{Patient characteristics}

In total, 749 African-American RA patients from CLEAR I and II were analyzed. The mean age at RA onset was 47.0 years, and $84.6 \%$ of patients were women. Median disease duration was 1.9 years; $86 \%$ of the patients had either anti$\mathrm{CCP}$ antibodies or RF.

Of the 749 RA participants, 156 (20.8\%) had rheumatoid nodules; these patients had more comparable ages at disease onset than did those without nodules but were more likely to have longer disease duration, a smoking history, higher HAQ scores, increased presence of joint-space narrowing and of autoantibodies, and higher levels of CRP (Table 1).

Radiographic scores at enrollment were available in 461 CLEAR I and CLEAR II RA participants. Of these 461 patients, 185 (40.1\%) patients had at least one radiographic erosion. RA participants with erosions were younger at RA onset, had longer disease duration, were more likely to have joint-space narrowing and autoantibodies, and to have been treated with methotrexate (Table 1).

The distribution of patients with other extraarticular manifestations was as follows: $16(2.2 \%)$ pulmonary fibrosis,
$21(2.9 \%)$ Sjögren syndrome, six $(0.8 \%)$ pericarditis, three $(0.4 \%)$ vasculitis, $11(1.5 \%)$ skin ulcers, and $16(2.2 \%)$ scleritis.

\section{Lack of association with IL4R genotype and disease susceptibility}

Each SNP was in Hardy-Weinberg equilibrium, and the frequencies were similar to those reported in other studies for rs 1805010 but different for rs 1801275 [8,32,33]. No significant differences were found in the genotype and allele frequencies between controls and RA patients. For rs 1805010 , frequencies were $23.7 \%$ and $26.5 \%$ for homozygous $\mathrm{AA}$ and GG genotypes, respectively, and $49.8 \%$ for the heterozygous AG genotype. Likewise, rs1801275 frequencies were $9.9 \%$ and $46.6 \%$ for homozygous AA and GG genotypes, respectively, and $43.5 \%$ for the heterozygous AG genotype.

\section{Association of IL4R SNPs with rheumatoid nodules}

No significant association between the rs 1801275 and rs1805010 alleles and rheumatoid nodules were found in the unadjusted and adjusted analyses (data not shown). After stratification for the presence of HLA-DRB1 SE and autoantibody status (RF or anti-CCP) in multivariable models, the rs 1801275 AA genotype $\left(\mathrm{OR}_{\mathrm{adj}}=8.08(95 \% \mathrm{CI}\right.$, 1.60 to 40.89$) ; P=0.01]$ and $\mathrm{AG}$ genotype $\left(\mathrm{OR}_{\mathrm{adj}}=2.97\right.$ ( $95 \% \mathrm{CI}, 1.08$ to 8.17 ), $P=0.04$ )] were found to be associated with rheumatoid nodules (Table 2). Similarly, stratifying separately by the presence of $H L A-D R B 1 \mathrm{SE}$ and antiCCP antibodies, the AA and AG genotypes of rs 1801275 were associated with rheumatoid nodules $\left(\mathrm{OR}_{\mathrm{adj}}=8.12\right.$ ( $95 \%$ CI, 1.59 to 41.44$), P=0.01$; and $\mathrm{OR}_{\mathrm{adj}}=2.96(95 \%$ CI, 1.15 to 7.62$), P=0.02$; respectively) in the multivariable model (data not shown). Likewise, stratifying separately by the presence of $H L A-D R B 1 \mathrm{SE}$ and $\mathrm{RF}$, the rs $1801275 \mathrm{AA}$ and $\mathrm{AG}$ genotypes $\left(\mathrm{OR}_{\mathrm{adj}}=8.45(95 \% \mathrm{CI}\right.$, 1.57 to 45.44$), P=0.01$; and $\mathrm{OR}_{\text {adj }}=3.57(95 \% \mathrm{CI}, 1.18$ to 10.76), $P=0.02$, respectively] and the rs 1805010 AA genotype $\left(\mathrm{OR}_{\mathrm{adj}}=4.52(95 \% \mathrm{CI}, 1.20\right.$ to 17.03$\left.), P=0.03\right)$ were associated with rheumatoid nodules (data not shown).

\section{Lack of association of IL4R SNPs with radiographic erosions}

No significant association between the presence of radiographic erosions and the SNPs examined was found in any of the unadjusted and adjusted analyses performed. Specifically, statistical significance was not reached after stratification by the presence or absence of HLA-DRBI SE and anti-CCP or RF status (alone or combination). These data are shown in Table 3.

\section{Discussion}

This is the first study conducted in African-American RA patients to determine the relation between the occurrence of rheumatoid nodules and erosions and the presence of the 
Table 1: Baseline sociodemographic, clinical, and laboratory characteristics of RA patients in the CLEAR registries as a function of the presence of erosions or rheumatoid nodules

\begin{tabular}{|c|c|c|c|c|c|c|}
\hline \multirow[b]{2}{*}{ Variable } & \multicolumn{3}{|c|}{ Radiographic erosions } & \multicolumn{3}{|c|}{ Rheumatoid nodules } \\
\hline & Present $n=185$ & Absent $n=276$ & Pf & Present $n=156$ & Absent $n=593$ & Pf \\
\hline $\begin{array}{l}\text { Age at RA onset, } \\
\text { years, mean (SD) }\end{array}$ & $45.3(14.5)$ & $48.3(12.6)$ & 0.02 & $45.6(12.6)$ & $47.8(13.6)$ & 0.06 \\
\hline $\begin{array}{l}\text { Disease duration, }{ }^{\mathrm{a}} \\
\text { years, median } \\
\left(\mathrm{IQR}^{\mathrm{b}}\right)\end{array}$ & $3.8(1.2-15.5)$ & $1.2(6.0-2.0)$ & $<0.0001$ & $7.5(1.3-15.6)$ & $1.8(0.8-8.0)$ & $<0.001$ \\
\hline $\begin{array}{l}\text { Smoking, ever, }{ }^{c} n \\
(\%)\end{array}$ & $98(54.4)$ & $139(51.9)$ & 0.59 & $95(61.7)$ & $295(50.3)$ & 0.01 \\
\hline $\begin{array}{l}\mathrm{HAQ}^{\mathrm{d}} \text { score, } \\
\text { median (IQR) }\end{array}$ & $2.0(1.3-2.4)$ & $1.8(0.9-2.4)$ & 0.27 & $2.1(1.3-2.6)$ & $1.8(1.0-2.4)$ & 0.01 \\
\hline $\begin{array}{l}\text { Joint-space } \\
\text { narrowing at } \\
\text { baseline, present } \\
(\text { score }>0), n(\%)\end{array}$ & $132(71.4)$ & $34(12.3)$ & $<0.001$ & $48(53.3)$ & $116(31.9)$ & $<0.001$ \\
\hline $\begin{array}{l}\text { Rheumatoid factor } \\
\text { positive, } n(\%)\end{array}$ & $145(87.3)$ & $182(74.3)$ & 0.001 & $127(90.7)$ & $418(77.1)$ & $<0.001$ \\
\hline $\begin{array}{l}\text { Anti-CCP antibody } \\
\text { positive, } n(\%)\end{array}$ & $148(81.3)$ & $159(59.3)$ & $<0.001$ & $127(84.1)$ & $375(65.2)$ & $<0.001$ \\
\hline $\begin{array}{l}\text { Abnormal C- } \\
\text { reactive protein } \\
(>5 \mathrm{mg} / \mathrm{L}), n(\%)\end{array}$ & $94(51.9)$ & $126(46.5)$ & 0.26 & $77(58.8)$ & $238(44.7)$ & $<0.004$ \\
\hline $\begin{array}{l}\text { HLA-DRB1 present, } \\
n(\%)\end{array}$ & 78 (42.9) & $113(41.1)$ & 0.71 & $64(43.2)$ & 234 (39.9) & 0.45 \\
\hline $\begin{array}{l}\text { Methotrexate use, } \\
\text { ever, }{ }^{\complement} n(\%)\end{array}$ & 149 (82.3) & 175 (64.6) & $<0.001$ & 127 (81.9) & 423 (72.2) & 0.01 \\
\hline
\end{tabular}

nonsynonymous IL4R SNPs rs 1805010 and rs 1801275 . We found that the rs $1801275 \mathrm{AA}$ and $\mathrm{AG}$ genotypes and the rs1805010 AA genotype were associated with rheumatoid nodules in African-American RA patients who are $H L A$ $D R B 1$ SE positive and autoantibody positive.

The minor allele frequency of rs 1805010 in African Americans patients with RA was found to be of similar frequency to that in the English and German studies $[8,18]$; in contrast, the minor allele frequency of rs 1801275 was found to be different from that in these two European populations. These findings must be considered to understand the disease phenotypes in patients of different ethnicities.

As expected, rheumatoid nodules were associated with disease duration, smoking, HAQ score, JSN, RF, anti-CCP antibodies, elevated CRP levels, and methotrexate use. However, HLA-DRB1 SE status alone does not appear to increase significantly the risk of rheumatoid nodules among
African Americans. Several studies conducted in patients of European descent found no association between the SE and rheumatoid nodules [34-37], whereas others found such an association [38,39]. Thus, the genetic predisposition to the development of rheumatoid nodules is complex and involves more than the presence of the SE and its interaction with environmental factors, such as smoking $[40,41]$ or medications [42]. However, the SE has a smaller absolute effect in African Americans than in individuals of European descent $[20,31]$.

The presence of radiographic erosions was associated with age, disease duration, the presence of JSN, RF, anti$\mathrm{CCP}$ antibodies, and methotrexate use, but it was not associated with HLA-DRBI SE, CRP levels, HAQ score, or smoking. After stratification by the presence of the SE and RF or anti-CCP antibodies (alone or in combination), no association between erosions and rs 1805010 or rs 1801275 
Table 2: Association of rs 1805010 and rs 1801275 with rheumatoid nodules after stratification by the presence of $H L A-$ DRB1 SE and autoantibodies in African Americans with RA

\begin{tabular}{|c|c|c|c|c|c|c|}
\hline \multirow[t]{2}{*}{ Variable } & \multirow[b]{2}{*}{$\begin{array}{l}\text { Rheumatoid } \\
\text { nodules } n(\%)\end{array}$} & \multirow[b]{2}{*}{$\begin{array}{l}\text { No rheumatoid } \\
\text { nodules } n(\%)\end{array}$} & \multicolumn{2}{|c|}{ Univariate analysis } & \multicolumn{2}{|c|}{ Multivariate analysis } \\
\hline & & & $\begin{array}{c}\text { Crude OR }(95 \% \\
\mathrm{Cl})\end{array}$ & $\boldsymbol{P}$ & Adjusted ${ }^{b}$ OR $(95 \% \mathrm{CI})$ & $P$ \\
\hline rs1805010, n (\%) & $\mathrm{n}=51^{\mathrm{a}}$ & $\mathrm{n}=171^{\mathrm{a}}$ & & & & \\
\hline AA & $17(33.3)$ & $31(18.1)$ & 1.61 (0.69 to 3.75$)$ & 0.27 & 2.74 (0.80 to 9.41$)$ & 0.11 \\
\hline AG & $20(39.2)$ & 99 (57.9) & 0.59 (0.27 to 1.28$)$ & 0.18 & $0.64(0.21$ to 1.96$)$ & 0.43 \\
\hline GG & $14(27.5)$ & $41(24.0)$ & 1.00 & -- & 1.00 & \\
\hline rs1801275, n(\%) & $\mathrm{n}=51^{\mathrm{a}}$ & $\mathrm{n}=172^{\mathrm{a}}$ & & & & \\
\hline AA & $7(13.7)$ & $14(8.1)$ & $2.44(0.86$ to 6.95$)$ & 0.09 & 8.08 ( 1.60 to 40.89$)$ & 0.01 \\
\hline AG & $27(52.9)$ & $75(43.6)$ & $1.76(0.89$ to 3.48$)$ & 0.11 & 2.97 (1.08 to 8.17$)$ & 0.04 \\
\hline GG & $17(33.3)$ & $83(48.3)$ & 1.00 & -- & 1.00 & -- \\
\hline
\end{tabular}

aPatients with HLA-DRB1 SE plus either anti-CCP or RF positive. ${ }^{b}$ Adjusted by age at RA onset (continuous) + Erosion + Gender + Disease duration ( $\geq 2$ years versus $<2$ years) + smoking (ever vs. never) + methotrexate (ever versus never).

was found. Similar data were reported by Marinou et al. [18] in a cross-sectional study of 965 white RA patients and 988 healthy controls; however, our data do not corroborate the report by Prots et al. [8] of a higher risk of developing early erosions, as noted in their longitudinal German cohort of 302 RA patients. Perhaps this effect was not observed because of the different racial/ethnic composition of the patients studied; in African Americans, these polymorphisms could be modulators of other phenotypes.

Because RF and anti-CCP antibodies have similar sensitivities, but anti-CCP antibodies have a higher specificity [27], we decided to stratify by these autoantibodies when assessing the relation with rheumatoid nodules and radiographic erosions. We found no association between $H L A$ DRBI SE/anti-CCP positivity with rheumatoid nodules or erosions, but a new association was found between rs1805010 (AA genotype) and HLA-DRB1 SE/RF positivity. Thus, $H L A-D R B 1 \mathrm{SE} / \mathrm{RF}$-positive patients with the AA genotype of rs 1805010 and the AA or AG genotype of rs1801275 have a higher risk of rheumatoid nodules than do those patients without this feature. The higher sensitivity and specificity of RF for the presence of extraarticular manifestations as compared with anti-CCP antibodies, as reported in other studies $[4,43,44]$, is a probable explanation for our findings.

There are several limitations to our study. Complete radiographic baseline data and genotyping are not available because the study is ongoing. Only $25 \%$ of CLEAR I RA participants had erosions at baseline, given the enrollment criterion of disease onset $<2$ years. In addition to restricting the analysis to a small number of subjects, the inclusion of early RA patients might miss a subset of patients who would go on to develop extraarticular manifestations with longer disease duration. Furthermore, we only analyzed two SNPs of ILR4, and our results could be influenced by the interactions of other SNPs within these genes or other genes whose proteins are associated with $\mathrm{T}_{\mathrm{H}} 1$-to- $\mathrm{T}_{\mathrm{H}} 2$ balance.

\section{Conclusions}

In conclusion, we found that both rs1801275 and rs1805010 are associated with rheumatoid nodules in African-American RA patients with the HLA-DRBI SE and autoantibodies. These findings may allow future stratification of the risk of extraarticular manifestations in RA.

\section{Abbreviations}

ACR: American College of Rheumatology; CCP: anti-cyclic citrullinated peptide antibodies; CLEAR: The Consortium for the Longitudinal Evaluation of African Americans with Early Rheumatoid Arthritis; CRP: C-reactive protein; DMARDs: disease-modifying antirheumatic drugs; ESR: erythrocyte sedimentation rate; GWASs: multiple genome-wide association studies; HAQ: Heath Assessment Questionnaire; IL-4: interleukin-4; JSN: joint-space narrowing; RA: rheumatoid arthritis; RF: rheumatoid factor; SE: shared epitope; SNPs: single-nucleotide polymorphisms.

\section{Competing interests}

The authors declare that they have no competing interests.

\section{Authors' contributions}

LBH, MID, DLC, BLJ, LFC, EAS, RB, LWM, GSA, and SLB investigators participated in the CLEAR study conception, recruiting of patients, and data acquisition. AVE and DVH performed radiographic evaluations. PIB, ZLC, AT, EEB, GSA, and LB participated in the design of the IL4R study. PIB, ZLC, and GSA wrote the initial 
Table 3: Association of rs 1805010 and rs 1801275 with radiographic erosions after stratification by the presence of $H L A-$ DRB1 SE and autoantibodies in African Americans with RA

\begin{tabular}{|c|c|c|c|c|c|c|}
\hline \multirow[t]{2}{*}{ Variable } & \multirow[b]{2}{*}{ Erosion $^{\mathrm{a}} n(\%)$} & \multirow[b]{2}{*}{ No erosion $n(\%)$} & \multicolumn{2}{|c|}{ Univariate analysis } & \multicolumn{2}{|c|}{ Multivariate analysis } \\
\hline & & & $\begin{array}{l}\text { Crude OR (95\% } \\
\text { CI) }\end{array}$ & $\boldsymbol{P}$ & Adjustedc OR (95\% CI) & $\boldsymbol{P}$ \\
\hline rs1805010, n (\%) & $\mathrm{n}=65^{\mathrm{b} t}$ & $\mathrm{n}=74^{\mathrm{b}}$ & & & & \\
\hline AA & $15(23.1)$ & $15(20.3)$ & $0.89(0.34$ to 2.36$)$ & 0.82 & $0.95(0.32$ to 2.86$)$ & 0.93 \\
\hline AG & $31(47.7)$ & $42(56.8)$ & $0.66(0.30$ to 1.47$)$ & 0.31 & $0.81(0.33$ to 1.99$)$ & 0.65 \\
\hline GG & $19(29.2)$ & $17(22.9)$ & 1.00 & -- & 1.00 & -- \\
\hline rs1801275, n (\%) & $\mathrm{n}=65^{\mathrm{b}}$ & $\mathrm{n}=75^{\mathrm{b}}$ & & & & \\
\hline AA & $3(4.6)$ & $9(12.0)$ & $0.31(0.08$ to 1.26$)$ & 0.10 & $0.30(0.06$ to 1.47$)$ & 0.14 \\
\hline AG & $28(43.1)$ & $34(45.3)$ & 0.78 (0.39 to 1.55$)$ & 0.47 & 0.64 (0.30 to 1.40$)$ & 0.27 \\
\hline GG & $34(52.3)$ & $32(42.7)$ & 1.00 & -- & 1.00 & -- \\
\hline
\end{tabular}

aErosion score $>0$ at enrollment; bPatients with HLA-DRB1 SE, plus either anti-CCP or RF positive; ${ }^{c}$ Adjusted by age at RA onset (continuous) + Gender + Disease duration ( $\geq 2$ years versus $<2$ years) + rheumatoid nodules + smoking (ever versus never) + methotrexate (ever versus never).

draft of the manuscript. AT performed the statistical analyses. AT, PIB, ZLC, JMK and EEB helped with the interpretation. All the authors helped with the final manuscript. All authors read and approved the final manuscript.

\section{Acknowledgements}

The Consortium for the Longitudinal Evaluation of African-Americans with Early Rheumatoid Arthritis (CLEAR) includes the following investigators: University of Alabama at Birmingham: S. Louis Bridges, Jr., MD, PhD (Director); Larry W. Moreland, MD (Co-Director) (currently at the University of Pittsburgh); George Howard, DrPH (Co-Director); Graciela S. Alarcón, MD, MPH; Emory University: Doyt L. Conn, MD; University of North Carolina: Beth L. Jonas, MD; Leigh F. Callahan, PhD; Medical University of South Carolina: Edwin A. Smith, MD; Gary S. Gilkeson, MD; and Washington University in St. Louis: Richard Brasington, MD. We gratefully acknowledge the following physicians, who also enrolled patients: Adahli Estrada Massey, MD, Auburn, AL; Runas Powers, MD, Alexander City, AL; Ben Wang, MD, Memphis, TN; Jacob Aelion, MD, Jackson, TN; Sohrab Fallahi, MD, Montgomery, AL; Richard Jones, PhD, MD, Tuscaloosa, AL; Donna Paul, MD, Montgomery, AL; and William Shergy, MD, Huntsville, AL. We gratefully acknowledge the staff and coordinators at the following sites: University of Alabama at Birmingham: Stephanie Ledbetter, MS; Selena Luckett-Smith, RN, CRNC; Laticia Woodruff, RN, MSN; Jinyi Wang; Yuanqing Edberg; Emory University: Joyce Carlone, RN, RNP; Karla Caylor, BSN, RN; Sharon Henderson, BSN, RN; University of North Carolina: Pat Cummins, RN; Diane Bresch, RN; Medical University of South Carolina: Trisha Sturgill; Donna Jordon; Kelley Gibson; and Washington University in St. Louis: Teresa Arb, RN, BSN, CCRC. This study was supported by NIH contract N01 AR-02247 and CCTS grants M01 RR 00032 (University of Alabama at Birmingham), M01 RR 00039 (Emory University/Grady Hospital), M01 RR 00046 (University of North Carolina), and M01 RR 01070 (Medical University of South Carolina). The work of Dr. Paula I. Burgos was also supported by Programa de Postgrado Beca Chile.

\section{Author Details}

'University of Alabama, Tuscaloosa, Alabama 35487, USA, ${ }^{2}$ Department of Clinical Immunology and Rheumatology, School of Medicine, Pontificia
Universidad Católica de Chile, Avenida Libertador Bernardo O'Higgins 340, Santiago, Chile, ${ }^{3}$ Leiden University Medical Center, Albinusdreef 2, 2333 ZA Leiden, The Netherlands, 4Emory University, 571 Kilgo Circle, Atlanta, GA 30322-1120, USA, 5 University of North Carolina at Chapel Hill, 130 Mason Farm Road, Chapel Hill, NC, USA, ${ }^{6}$ Medical University of South Carolina, Jonathan Lucas Street, Charleston, SC29425, USA, 7Washington University in St. Louis, 4444 Forest Park Avenue, St Louis, MO 63108-2259, USA and ${ }^{8}$ Current address: The University of Pittsburgh, Pittsburgh, PA 15260, USA

Received: 25 February 2010 Revised: 22 April 2010

Accepted: 5 May 2010 Published: 5 May 2010

\section{References}

1. Silman AJ, Pearson JE: Epidemiology and genetics of rheumatoid arthritis. Arthritis Res 2002, 4:S265-272.

2. Anaya J-M, Correa PA, Mantilla RD, Jimenez F, Kuffner T, McNicholl JM: Rheumatoid arthritis in African Colombians from Quibdo. Semin Arthritis Rheum 2001 in press.

3. Silman AJ, MacGregor AJ, Thomson W, Holligan S, Carthy D, Farhan A, Ollier WER: Twin concordance rates for rheumatoid arthritis: results from a nationwide study. Br J Rheumatol 1993, 32:903-907.

4. De Rycke L, Peene I, Hoffman IEA, Kruithof E, Union A, Meheus L, Lebeer K, Wyns B, Vincent C, Mielants H, Boullart L, Serre G, Veys EM, De Keyser F: Rheumatoid factor and anticitrullinated protein antibodies in rheumatoid arthritis: diagnostic value, associations with radiological progression rate, and extra-articular manifestations. Ann Rheum Dis 2004, 63:1587-1593.

5. Thomson W, Harrison B, Ollier B, Wiles N, Payton T, Barrett J, Symmons D, Silman A: Quantifying the exact role of HLA-DRB1 alleles in susceptibility to inflammatory polyarthritis: results from a large, population-based study. Arthritis Rheum 1999, 42:757-762.

6. Jawaheer D, Seldin MF, Amos Cl, Chen WV, Shigeta R, Monteiro J, Kern M, Criswell LA, Albani S, Clegg DO, Pope R, Schroeder HW Jr, Bridges SL Jr, Pisetsky DS, Ward R, Kastner DL, Wilder RL, Pincus T, Callahan LF, Flemming D, Wener $\mathrm{MH}$, Gregersen PK: A genomewide screen in multiplex rheumatoid arthritis families suggests genetic overlap with other autoimmune diseases. Am J Human Gene 2001, 68:927-936.

7. Burton PR, Clayton DG, Cardon LR, Craddock N, Deloukas P, Duncanson A, Kwiatkowski DP, McCarthy MI, Ouwehand WH, Samani NJ, Todd JA, 
Donnelly P, Barrett JC, Davison D, Easton D, Evans D, Leung HT, Marchini JL, Morris AP, Spencer CCA, Tobin MD, Attwood AP, Boorman JP, Cant B, Everson U, Hussey JM, Jolley JD, Knight AS, Koch K, Meech E, et al:: Genome-wide association study of 14,000 cases of seven common diseases and 3,000 shared controls. Nature 2007, 447:661-678.

8. Prots I, Skapenko A, Wendler J, Mattyasovszky S, Yone CL, Spriewald B, Burkhardt H, Rau R, Kalden JR, Lipsky PE, Schulze-Koops H: Association of the IL4R single-nucleotide polymorphism $150 \mathrm{~V}$ with rapidly erosive rheumatoid arthritis. Arthritis Rheum 2006, 54:1491-1500.

9. Genevay S, di Giovine FS, Perneger TV, Silvestri T, Stingelin S, Duff G, Guerne PA: Association of interleukin-4 and interleukin-1B gene variants with Larsen score progression in rheumatoid arthritis. Arthritis Rheum 2002, 47:303-309.

10. Moreno O, Gonzalez Cl, Saaibi DL, Otero W, Badillo R, Martin J, Ramirez G: Polymorphisms in the IL4 and IL4RA genes in Colombian patients with rheumatoid arthritis. J Rheumatol 2007, 34:36-42.

11. Skapenko A, Wendler J, Lipsky PE, Kalden JR, Schulze-Koops H: Altered memory $T$ cell differentiation in patients with early rheumatoid arthritis. J Immunol 1999, 163:491-499.

12. Skapenko A, Niedobitek GU, Kalden JR, Lipsky PE, Schulze-Koops H: The Th2 cytokines IL-4 and IL-10 are internal controllers of human Th1biased immunity in vivo. Arthritis Res Ther 2003, 5:S88.

13. Deichmann K, Bardutzky J, Forster J, Heinzmann A, Kuehr J: Common polymorphisms in the coding part of the IL4-receptor gene. Biochem Biophys Res Commun 1997, 231:696-697.

14. Kruse S, Japha T, Tedner M, Sparholt SH, Forster J, Kuehr J, Deichmann KA, Abello A: The polymorphisms S503P and Q576R in the interleukin-4 receptor alpha gene are associated with atopy and influence the signal transduction. Immunology 1999, 96:365-371.

15. Hershey GKK, Friedrich MF, Esswein LA, Thomas ML, Chatila TA: The association of atopy with a gain-of-function mutation in the alpha subunit of the interleukin-4 receptor. NEng/ J Med 1997, 337:1720-1725.

16. Mitsuyasu $\mathrm{H}$, Yanagihara $\mathrm{Y}$, Mao XQ, Gao PS, Arinobu Y, Ihara K, Takabayashi A, Hara T, Enomoto T, Sasaki S, Kawai M, Hamasaki N, Shirakawa T, Hopkin JM, Izuhara K: Cutting edge: dominant effect of Ile50Val variant of the human IL-4 receptor alpha-chain in IgE synthesis. J Immuno/ 1999, 162:1227-1231.

17. Battle NC, Choudhry S, Tsai HJ, Eng C, Kumar G, Beckman KB, Naqvi M, Meade K, Watson HG, LeNoir M, Burchard EG: Ethnicity-specific genegene interaction between IL-13 and IL-4R alpha among African American with asthma. Am J Resp Crit Care Med 2007, 175:881-887.

18. Marinou I, Till SH, Moore DJ, Wilson AG: Lack of association or interactions between the IL-4, IL-4R alpha and IL-13 genes, and rheumatoid arthritis. Arthritis Res Ther 2008, 10:R80.

19. Austin JS, Ambrose RF, Young PK, Moreland LW, Alarcón GS: Rheumatoid arthritis patients and clinical drugs trials: a case-control study. Arthritis Care Res 1991, 4:22-26.

20. McDaniel DO, Alarcón GS, Pratt PW, Reveille JD: Most African-American patients with rheumatoid arthritis do not have the rheumatoid antigenic determinant (epitope). Ann Intern Med 1995, 123:181-187.

21. Alarcón GS, Barger BO, Acton RT, Koopman WJ: HLA antigens and gold toxicity in American blacks with rheumatoid arthritis. Rheumatol Int 1986, 6:13-17.

22. Alarcón GS, Koopman WJ, Acton RT, Barger BO: DR antigen distribution in blacks with rheumatoid arthritis. J Rheumatol 1983, 10:579-583.

23. Arnett FC, Edworthy SM, Bloch DA, McShane DJ, Fries JF, Cooper NS, Kaplan SR, Liang MH, Luthra HS, et al:: The American Rheumatism Association 1987 revised criteria for the classification of rheumatoid arthritis. Arthritis Rheum 1988, 31:315-324

24. US Department of Commerce, Bureau of the Census: Current Population reports, Series P-23, No. 28 and Series P-60, No. 68 and Subsequent yeArs. Washington, DC: Housing and Household Economic Statistics Division; 1995

25. Felson DT, Anderson J, Boers M, Bombardier C, Chernoff M, Fried B: The American College of Rheumatology preliminary core set of disease activity measures for rheumatoid arthritis clinical trials. Arthritis Rheum 1993, 36:729-740

26. Fries JF, Spitz P, Kraines G, Holman HR: Measurement of patient outcome in arthritis. Arthritis Rheum 1980, 23:137-145.

27. Mikuls TR, Holers VM, Parrish L, Kuhn KA, Conn DL, Gilkeson G, Smith EA, Kamen DL, Jonas BL, Callahan LF, Alarcon GS, Howard G, Moreland LW, Bridges SL Jr: Anti-cyclic citrullinated peptide antibody and rheumatoid factor isotypes in African Americans with early rheumatoid arthritis. Arthritis Rheum 2006, 54:3057-3059.

28. van der Heijde D: How to read radiographs according to the Sharp/van der Heijde method. J Rheumatol 2000, 27:261-263.

29. van der Heijde DM, van Riel PL, Nuver-Zwart IH, Gribnau FW, vad de Putte LB: Effects of hydroxychloroquine and sulphasalazine on progression of joint damage in rheumatoid arthritis. Lancet 1989, 1:1036-1038

30. Smolen JS, van der Heijde DM, Aletaha D, Xu S, Han J, Baker D, St Clair EW: Progression of radiographic joint damage in rheumatoid arthritis: independence of erosions and joint space narrowing. Ann Rheum Dis 2009:1535-40

31. Hughes $L B$, Morrison D, Kelley JM, Padilla MA, Vaughan LK, Westfall $A O$, Dwivedi H, Mikuls TR, Holers VM, Parrish LA, Alarcon GS, Conn DL, Jonas BL, Callahan LF, Smith EA, Gilkeson GS, Howard G, Moreland LW, Patterson $N$, Reich D, Bridges SL Jr: The HLA-DRB1 shared epitope is associated with susceptibility to rheumatoid arthritis in African Americans through European genetic admixture. Arthritis Rheum 2008, 58:349-358.

32. Hackstein $\mathrm{H}$, Hofmann $\mathrm{H}$, Bohnert A, Bein G: Definition of human interleukin-4 receptor alpha chain haplotypes and allelic association with atopy markers. Hum Immunol 1999, 60:1119-1127.

33. Howard TD, Koppelman GH, Xu J, Zheng SL, Postma DS, Meyers DA, Bleecker ER: Gene-gene interaction in asthma: IL4RA and IL13 in a Dutch population with asthma. Am J Hum Genet 2002, 70:230-236.

34. Ioannidis JPA, Tarassi K, Papadopoulos IA, Voulgari PV, Boki KA, Papasteriades CA, Drosos AA: Shared epitopes and rheumatoid arthritis: disease associations in Greece and meta-analysis of Mediterranean European populations. Semin Arthritis Rheum 2002, 31:361-370.

35. Hakala M, Silvennoinen Kassinen S, Ikaheimo I, Isosomppi J, Tiilikainen A. HLA markers in a community-based rheumatoid arthritis series. Ann Med 1997, 29:291-296

36. Lequerre T, Gauthier-Jauneau AC, Bansard C, Derambure C, Hiron M, Vittecoq O, Daveau M, Mejjad O, Daragon A, Tron F, Le LX, Salier JP: Gene profiling in white blood cells predicts infliximab responsiveness in rheumatoid arthritis. Arthritis Res Ther 2006, 8:R105.

37. Gorman JD, David-Vaudey E, Pai M, Lum RF, Criswell LA: Lack of association of the HLA-DRB1 shared epitope with rheumatoid nodules: an individual patient data meta-analysis of 3,272 Caucasian patients with rheumatoid arthritis. Arthritis Rheum 2004, 50:753-762.

38. Weyand CM, Hicok KC, Conn DL, Goronzy JJ: The influence of HLA-DRB1 genes on disease severity in rheumatoid arthritis. Ann Intern Med 1992, 117:801-806.

39. Salvarani C, Macchioni P, Mantovani W, Rossi F, Veneziani M, Boiardi L, Lodi L, Portioli I: Extraarticular manifestations of rheumatoid arthritis and HLA antigens in northern Italy. J Rheumatol 1992, 19:242-246.

40. Mattey DL, Dawes PT, Fisher J, Brownfield A, Thomson W, Hajeer AH, Ollier WER: Nodular disease in rheumatoid arthritis: association with cigarette smoking and HLA-DRB1/TNF gene interaction. J Rheumatol 2002, 29:2313-2318.

41. Wolfe F: The effect of smoking on clinical, laboratory, and radiographic status in rheumatoid arthritis. J Rheumatol 2000, 27:630-637.

42. Combe B, Didry C, Gutierrez M, Anaya J-M, Sany J: Accelerated nodulosis and systemic manifestations during methotrexate therapy for rheumatoid arthritis. Eur J Med 1993, 2:153-156.

43. Bas S, Perneger TV, Mikhnevitch E, Seitz M, Tiercy JM, Roux-Lombard P, Guerne PA: Association of rheumatoid factors and anti-filaggrin antibodies with severity of erosions in rheumatoid arthritis. Rheumatology 2000, 39:1082-1088.

44. Mikuls TR, Hughes $L B$, Westfall $A O$, Holers VM, Parrish $L$, van der HD, van Everdingen M, Alarcon GS, Conn DL, Jonas B, Callahan LF, Smith EA, Gilkeson G, Howard G, Moreland LW, Bridges SL Jr: Cigarette smoking, disease severity and autoantibody expression in African Americans with recent-onset rheumatoid arthritis. Ann Rheum Dis 2008, 67:1529-1534

doi: $10.1186 /$ ar2994

Cite this article as: Burgos et al., Association of IL4R single-nucleotide polymorphisms with rheumatoid nodules in African Americans with rheumatoid arthritis Arthritis Research \& Therapy 2010, 12:R75 